\title{
KONTRIBUSI HASIL HUTAN BUKAN KAYU KEMIRI (Aleurites moluccana) TERHADAP PENDAPATAN PETANI HKm TANGGA DESA SELENGEN KECAMATAN KAYANGAN KABUPATEN LOMBOK UTARA
}

\author{
Contribution of Non-Timber Forest Products Candlenut (Aleurites Moluccana) \\ Lombok Regency \\ Nihad Kartila, Andi Chairil Ichsan, dan Markum \\ Program Studi Kehutanan, Universitas Mataram \\ Jln. Majapahit No 62, Mataram, NTB \\ E-mail ; nihadkartila6@gmail.com
}

To Farmer's Income of Tangga Community Forest Selengen Village Kayangan District North

\begin{abstract}
This research was intended to find Contribution of Non-Timber Forest Products Candlenut (Aleurites Moluccana) to Farmer's Income of Tangga, supporting and inhibiting factors, and income improvement strategy of business non-timber forest products candlenut. The research location in Tangga hamlet, Selengen Village, Kayangan District, North Lombok Regency, West Nusa Tenggara Province. This research used interview method with questionnaire tool to 36 respondents was carried on February 2018. The results showed Contribution of Non-Timber Forest Products Candlenut from region farmer community to farmer's income was $63.2 \%$ /area of arable land or $63 \%$ /hectares, which support farmers to cultivate candlenut because it is very easy to develop, does not require intensive maintenance, harvest activities were very easy to do, technology tools used were traditional, and marketing process was easy to do. As well as barriers in the miscellaneous management of the lack of capital and the availability of limited tools in the processing of candlenut so that farmers can only sell candlenut in the form of logs that will reduce the income it receives, as well as the lack of knowledge and skills possessed by farmers. Income-generating strategy of the candlenut can be done with SO strategy (StrenghtOpportunity) that is developing the potency of candlenut with skill owned by farmer by utilizing simple tool technology. As well as increased cultivation and intensive candlenut intensive maintenance by utilizing the existing land area. And the strengthening of institutional governance can be done by conducting counseling and training activities. Business governance such as product innovation and market network improvement is done by improving product packaging (branding) to tie consumer appeal. And the governance of the region can be done by applying agroforestry system (plant spacing).
\end{abstract}

Keywords: Community Forest, Contribution of Candlenut, Farmer's Income

\begin{abstract}
Abstrak
Penelitian ini bertujuan untuk mengetahui kontribusi Hasil Hutan Bukan Kayu Kemiri terhadap pendapatan petani HKm (Hutan Kemasyarakatan) Tangga, faktor pendukung dan penghambat, serta strategi peningkatan pendapatan dari usaha hasil hutan bukan kayu Kemiri. Lokasi penelitian terletak di Dusun Tangga Desa Selengen Kecamatan Kayangan Kabupaten Lombok Utara Provinsi Nusa Tenggara Barat. Penelitian ini menggunakan metode wawancara dengan alat bantu kuesioner terhadap 36 responden yang dilaksanakan pada bulan Februari 2018. Hasil Penelitian menunjukkan bahwa kontribusi hasil hutan bukan kayu kemiri dari kawasan hutan kemasyarakatan terhadap pendapatan petani adalah
\end{abstract}


sebesar $63,2 \%$ per luas lahan garapan atau $63 \%$ per hektar, hal yang mendukung petani melakukan budidaya kemiri karena sangat mudah dikembangkan, tidak memerlukan pemeliharaan yang intensif, kegiatan panen yang sangat mudah dilakukan, teknologi alat yang digunakan bersifat tradisional, dan proses pemasaran yang mudah dilakukan. Serta hambatan dalam pengelolaan kemiri kurangnya modal dan ketersediaan alat yang terbatas dalam pengolahan kemiri sehingga petani hanya mampu menjual kemiri dalam bentuk gelondongan saja yang akan mengurangi pendapatan yang diterimanya, serta kurangnya pengetahuan dan keterampilan yang dimiliki oleh petani. Strategi peningkatan pendapatan dari usaha kemiri dapat dilakukan dengan strategi SO (Strenght-Opportunity) yaitu mengembangkan potensi kemiri dengan meningkatkan kinerja Sumber Daya Manusia (SDM) dengan pemanfaatan teknologi yang ada. Serta penguatan kelembagaan dan mengadakan pemeliharaan kemiri yang intensif dengan memanfaatkan lahan kawasan yang ada. Dan penguatan tata kelola kelembagaan dapat dilakukan dengan melakukan kegiatan penyuluhan dan pelatihan. Tata kelola usaha seperti inovasi produk dan perbaikan jaringan pasar dilakukan dengan cara perbaikan kemasan produk (branding) untuk mengikat daya tarik konsumen. Dan tata kelola kawasan dapat dilakukan dengan menerapkan sistem agroforestri (pengaturan jarak tanam).

Kata Kunci: Hutan Kemasyarakatan, Kontribusi Kemiri, Pendapatan Petani

\section{Pendahuluan}

Sumber daya hutan mempunyai potensi multifungsi yang dapat memberikan manfaat ekonomi, lingkungan dan sosial bagi kesejahteraan masyarakat sekitar hutan. Salah satu upaya pemerintah untuk meningkatkan kesejahteraan masyarakat dengan membentuk Hutan Kemasyarakatan, berdasarkan Peraturan Menteri Kehutanan Nomor P.83/MenLHK/Setjen/ KUM.1/10/2016 Hutan Kemasyarakatan adalah hutan negara yang pemanfaatan utamanya ditujukan untuk memberdayakan masyarakat setempat.

Provinsi Nusa Tenggara Barat termasuk daerah yang aktif mengusulkan Penetapan Areal Kerja untuk Hutan Kemasyarakatan. Data yang ada di Kementerian Kehutanan (2014), menunjukkan bahwa Nusa Tenggara Barat telah mendapatkan penetapan areal kerja seluas $24.601,5$ ha dan dari luas tersebut, sebesar $34,59 \%$ sudah ditindak-lanjuti dengan penerbitan Izin Usaha Pemanfaatan Hutan Kemasyarakatan (IUPHKm) oleh Bupati/Walikota. Jumlah Izin Usaha Pemanfaatan Hutan Kemasyarakatan di Nusa Tenggara Barat mencapai areal seluas $14.078,50$ ha. Luas tersebut terdistribusi di sebanyak 8 kabupaten/kota (Markum, et al, 2014).

Program Hutan Kemasyarakatan tersebut, telah memberikan kesempatan bagi masyarakat di sekitar kawasan hutan untuk mendapat hak pengelolaan. Hasil nyata yang telah dirasakan oleh masyarakat melalui program Hutan Kemasyarakatan adalah meningkatnya produksi hasil hutan bukan kayu, dimana setiap lokasi memiliki produk unggulannya masing-masing (Markum, et al. 2014). Pola pengusahaan hasil hutan bukan kayu pada areal Hutan Kemasyarakatan sebagian besar merupakan hasil budidaya melalui sistem agroforestri dan hanya beberapa jenis hasil hutan bukan kayu saja yang sebagian besarnya masih merupakan produk alam (Silamon, 2014).

Hasil Hutan Bukan Kayu atau Non Timber Forest Product memiliki nilai yang sangat strategis. Hasil hutan bukan kayu merupakan salah satu sumberdaya hutan yang memiliki komparatif dan bersinggungan langsung dengan masyarakat di sekitar hutan. Berdasarkan Peraturan Menteri Kehutanan Nomor P.55/Menhut-II/2006 tentang penataan hasil hutan yang berasal dari hutan Negara menyatakan bahwa, Hasil Hutan Bukan Kayu (HHBK) adalah hasil hutan selain kayu yang dipungut dari dalam hutan lindung maupun hutan produksi. 
Pulau Lombok memiliki potensi hasil hutan bukan kayu cukup besar baik yang berada di dalam kawasan maupun di luar kawasan hutan. Berdasarkan hasil penelitian Rencana Pengelolaan hasil hutan bukan kayu di Kabupaten Lombok Utara, terdapat sejumlah komoditas yang dikembangkan oleh masyarakat. Di Kabupaten Lombok Utara, potensi hasil hutan bukan kayu di dalam kawasan hutan yakni di dalam kawasan $\mathrm{HKm}$ sebanyak 27 komoditi dan di luar HKm sebanyak 19 komoditi. Sedangkan potensi HHBK di luar kawasan hutan sebanyak 25 komoditi (WWF, 2012). Atas dasar potensi tersebut, dengan berpedoman pada Peraturan Menteri Kehutanan Nomor P.35/Menhut II/2007 tentang Hasil Hutan Bukan Kayu dan Permenhut Nomor P.21/Menhut-II/2009 tentang penentuan komoditas HHBK unggulan, maka pemerintah daerah Kabupaten Lombok Utara telah menetapkan 2 komoditas HHBK unggulan, salah satunya adalah kemiri. Tanaman kemiri telah lama diketahui sebagai komoditi HHBK yang sangat penting dan potensial untuk berbagai penggunaan dan sumber penghasilan masyarakat. Berbagai macam produk dapat dihasilkan dari bahan baku kemiri dan secara nyata telah memberikan kontribusi terhadap pendapatan masyarakat. Produk kemiri juga telah lama menjadi bagian penting dalam kehidupan masyarakat (FFI, 2011)

Awal keberadaan kemiri di Kabupaten Lombok Utara tidak diketahui dengan pasti, bahkan menurut informasi dari masyarakat keberadaan kemiri sudah ada sejak sebelum diterapkan program Hutan Kemasyarakat di daerah tersebut. Populasi tanaman kemiri juga tidak diketahui dengan pasti akan tetapi dari sisi luas areal yang terindikasi ada tanaman kemiri dalam kawasan Hutan Kemasyarakatan mencapai luas total 617 ha di empat desa, yaitu: di Desa Salut 350 ha, Desa Selengen (Dusun Tangga) 87 ha, Desa Mumbul Sari 180 ha dan Desa Akar-Akar 100 ha (WWF, 2016).

Desa Selengen (Dusun Tangga) merupakan salah satu desa yang memiliki potensi tanaman kemiri yang berada didalam kawasan hutan kemasyarakatan. Hutan Kemasyarakatan di Desa Selengen terbentuk pada tahun 1999 dan mendapat Izin Usaha Pemanfaatan Hutan Kemasyarakatan (IUPHKm) pada tahun 2013 yang terletak di Dusun Tangga, yang sebagian besar masyarakatnya memanfaatkan dan mengelola kemiri. Kemiri yang berada di dalam kawasan hutan kemasyarakatan mampu memberikan kontribusi kepada masyarakat yang berada di sekitar kawasan karena kemiri yang mudah didapatkan, tumbuh secara liar, dan jarang diserang oleh hama.

Berdasarkan uraian diatas maka sangat perlu untuk dilakukan penelitian terkait dengan "Kontribusi HHBK Kemiri Terhadap Pendapatan Petani HKm Tangga Kecamatan Kayangan Kabupaten Lombok Utara", dengan harapan setelah melihat nilai tersebut maka tidak perlu diragukan lagi bahwa kemiri sebagai HHBK sangat penting untuk dikembangkan.

Dengan demikian fokus penelitian ini bertujuan untuk mengetahui kontribusi hasil hutan bukan kayu kemiri terhadap pendapatan petani, faktor pendukung dan penghambat terhadap usaha kemiri, serta menyusun strategi peningkatan pendapatan petani dari usaha kemiri.

\section{Metode}

Penelitian ini dilaksanakan di HKm Tangga yang terletak di Dusun Tangga, Desa Selengen, Kecamatan Kayangan, Kabupaten Lombok Utara. Penelitian ini dilaksanakan pada bulan Februari 2018.

Penelitian ini termasuk dalam penelitian deskriptif dengan pendekatan kualitatif dan kuantitatif. Data yang diperlukan dalam penelitian terdiri dari data primer dan sekunder. Data primer diperoleh dari pengamatan langsung ke lokasi dengan melakukan wawancara terbuka dengan menggunakan serangkaian pertanyaan dalam bentuk kuesioner. Sedangkan data sekunder digunakan sebagai data penunjang data primer yang diperoleh dari studi kepustakaan dan lembaga-lembaga terkait yang mendukung penelitian ini.

Penentuan daerah sampel dilakukan dengan menggunakan teknik Non probability sampling yaitu Purposive sampling. Menurut Sugiyono (2016) Purposive sampling 
merupakan teknik penentuan daerah sampel dengan pertimbangan tertentu. Dusun Tangga dipilih sebagai daerah penelitian dengan pertimbangan bahwa sebagian besar petani $\mathrm{HKm}$ Tangga yang mengelola Hasil Hutan Bukan Kayu (HHBK) Kemiri terdapat pada Dusun Tangga. Sedangkan responden dalam penelitian ini adalah seluruh petani HKm Tangga yang mengelola Hasil Hutan Bukan Kayu (HHBK) Kemiri yang terdapat di Dusun Tangga. Penelitian ini dilakukan dengan teknik sampling jenuh (sensus). Menurut Sugiyono (2016) Sampling jenuh adalah teknik penentuan sampel bila semua anggota populasi digunakan sebagai sampel, dimana terdapat 36 anggota petani HKm.

Metode analisa data dijabarkan sebagai berikut. Menurut Husinsyah (2006, cit. Sudarman, et al. 2001) total biaya menggunakan persamaan sebagai berikut:

Keterangan :

$$
\mathrm{TC}=\mathrm{TFC}+\mathrm{TVC}
$$

$\mathrm{TC}=$ Total Biaya (Total Cost) (Rp/Tahun)

TFC = Total Biaya Tetap (Total Fixed Cost) (Rp/Tahun)

TVC $=$ Total Biaya Variabel (Total Variabel Cost) (Rp/Tahun)

Menurut Husinsyah (2006, cit. Samuelson, et al. 2003) untuk menghitung besarnya penerimaan ditentukan dengan menggunakan rumus sebagai berikut:

$$
\mathrm{TR}=\mathrm{Pq} \text {. } \mathrm{Q} \text {. }
$$

Keterangan :

TR = Total Penerimaan (Total Revenue);

$\mathrm{Pq}=$ Harga Produk (Rp/tahun);

$\mathrm{Q}=$ Jumlah Produksi $(\mathrm{kg})$.

Untuk mengetahui besarnya pendapatan yang dalam mengusahakan kemiri, maka digunakan rumus (Soekartawi, 2006) sebagai berikut:

$$
P_{d}=T R-T C
$$

Keterangan:

$\mathrm{P}_{\mathrm{d}}=$ Pendapatan dari usaha kemiri (Rp/tahun)

TR $=$ Total penerimaan dari usaha kemiri (Rp/tahun)

TC $=$ Total biaya dari usaha kemiri

Pendapatan total petani dihitung dengan menjumlahkan pendapatan baik diperoleh dari usaha kemiri dan non kemiri dengan rumus:

$$
P_{t}=P_{1}+P_{2}
$$

Keterangan:

$\mathrm{P}_{\mathrm{t}}=$ Pendapatan total petani $(\mathrm{Rp})$

$\mathrm{P}_{1}=$ Pendapatan dari usaha kemiri $(\mathrm{Rp})$

$\mathrm{P}_{2}=$ Pendapatan dari usaha non kemiri $(\mathrm{Rp})$

Untuk mengetahui besarnya sumbangan (kontribusi) dari usaha kemiri terhadap pendapatan total petani dihitung dengan rumus Husinsyah (2006 cit. Sudarman, et al. 2001):

$$
K=\frac{\mathrm{Pd}}{\mathrm{Pt}} \times 100 \%
$$

Keterangan:

$\mathrm{K}=$ Kontribusi usaha kemiri (\%)

$\mathrm{P}_{\mathrm{d}}=$ Pendapatan petani dari usaha kemiri $(\mathrm{Rp})$

$P_{t}=$ Pendapatan total petani $(R p)$

Untuk mengetahui faktor pendukung dan penghambat petani dalam mengusahakan kemiri dianalisis menggunakan analisis deskriptif. Sedangkan strategi peningkatan pendapatan usaha kemiri menggunakan analisis SWOT. 


\begin{tabular}{|c|c|c|}
\hline INTERNAL EKSTERNAL & OPPORTUNITY & TREATHS \\
\hline STRENGHT & Strategi S-O & Strategi S-T \\
\hline WEAKNESS & Strategi W-O & Strategi W-T \\
\hline
\end{tabular}

Gambar 1. Matrik SWOT.

Figure 1. Matrix SWOT.

Posisi kuadran yang tertuang dalam Gambar 1. dapat memberikan penjelasan tentang penyusunan strategi peningkatan pendapatan dari kemiri.

a) Strategi SO (Strengths Opportunities)

Strategi SO yaitu dengan menggunakan seluruh kekuatan untuk merebut dan memanfaatkan peluang sebesar-besarnya.

b) Strategi ST (Strengths Threats)

Strategi ST merupakan strategi yang menggunakan kekuatan yang dimiliki objek untuk mengatasi ancaman.

c) Strategi WO (Weaknesses Opportunities)

Strategi WO ini ditetapkan berdasarkan pemanfaatan peluang yang ada dengan cara meminimalkan kelemahan yang ada.

d) Strategi WT (Weaknesses Threats)

Strategi WT ditetapkan dengan meminimalkan kelemahan-kelemahan yang ada serta menghindari ancaman.

\section{Hasil dan Pembahasan}

\section{Karakteristik Responden}

Karakteristik responden merupakan gambaran umum mengenai latar belakang dan keadaan petani, berdasarkan hasil penelitian dan wawancara terhadap 36 responden di $\mathrm{HKm}$ Tangga diketahui bahwa sebagian besar yang melakukan kegiatan pengelolaan kemiri adalah petani yang masih termasuk dalam golongan usia produktif. Petani yang masih tergolong usia produktif sangat dimungkinkan untuk dapat meningkatkan keterampilannya dalam mengelola kemiri dan dapat menyerap teknologi baru dalam rangka peningkatan pendapatannya. Petani telah memiliki kesadaran akan pentingnya pendidikan meskipun sebagian besar hanya tamatan Sekolah Dasar, rendahnya tingkat pendidikan tersebut akan berpengaruh terhadap sikap petani dalam mengambil keputusan terkait dengan kegiatan pengelolaan kemiri yang dilakukan dan penyerapan teknologi baru. Rata-rata luas lahan garapan yang dimiliki oleh petani adalah 0,81 hektar.

HKm Tangga merupakan hutan kemasyarakatan yang mengelola kemiri yang dibuka sejak tahun 1999 dan mulai mendapatkan izin kelola dari kementerian kehutanan pusat pada tahun 2013 dengan jumlah penggarap sebanyak 59 kepala keluarga dengan luas lahan yang telah berizin seluas 87 hektar yang terdiri dari 2 blok yaitu blok 1 dan blok 2 dimana pemisah antara kedua blok tersebut adalah jalan setapak. Di kawasan $\mathrm{HKm}$ Tangga didominasi oleh tanaman hasil hutan bukan kayu Kemiri, disamping itu juga terdapat tanaman kopi dan kakao. 


\section{Produksi dan Nilai Produksi}

Produksi kemiri yang dimaksud dalam penelitian ini adalah kegiatan petani untuk menghasilkan kemiri yang dinyatakan dalam satuan kilogram $(\mathrm{kg})$. Dalam penelitian ini petani menghasilkan kemiri dalam bentuk gelondongan, produksi kemiri yang dihasilkan petani sangat mempengaruhi pendapatan semakin tinggi produksi kemiri maka semakin tinggi pula pendapatan yang diperoleh.

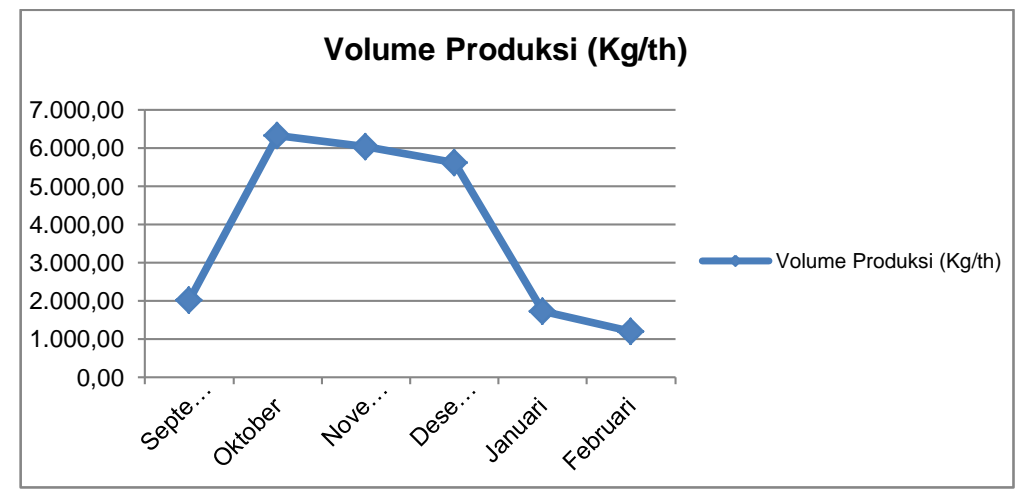

Gambar 2. Volume Produksi Kemiri.

Figure 2. Volume of Candlenut Production.

Berdasarkan hasil penelitian diketahui bahwa kegiatan panen kemiri berlangsung selama 6 bulan dengan jumlah produksi kemiri yakni sebesar $22.945 \mathrm{~kg} / \mathrm{th}$ dengan rata-rata jumlah produksi untuk setiap petani sebesar $637,36 \mathrm{~kg} / \mathrm{org} / \mathrm{th}$ dengan harga jual kemiri yakni sebesar Rp 4.000 - 6.000 dengan rata-rata harga produksi Rp 5.083 per tahun.

Rata-rata nilai produksi kemiri per tahun diperoleh dari penjumlahan keseluruhan nilai produksi yang diperoleh oleh petani dan kemudian dibagi dengan jumlah petani sehingga diperoleh jumlah nilai produksi per luas lahan garapan selama satu tahun dengan rata-rata nilai produksi setiap petani sebesar Rp 3.259.028 /org/LLG/th. Sedangkan rata-rata nilai produksi kemiri per hektar diperoleh dari pembagian masing-masing nilai produksi kemiri dengan masing-masing luas lahan garapan petani kemiri kemudian jumlah dari keseluruhan nilai produksi per hektar dibagi dengan jumlah petani responden kemiri sehingga diperoleh nilai produksi rata-rata untuk setiap responden sebesar Rp 4.021.640 /org/ha/th.

\section{Total Biaya Produksi Kemiri}

Total biaya produksi adalah jumlah biaya yang dikeluarkan untuk mengelola kemiri yang terdiri dari biaya tetap dan biaya variabel.

Tabel 1. Total Biaya Produksi Kemiri.

Table 1. Total Cost of Candlenut Production.

\begin{tabular}{cccr}
\hline No. & \multicolumn{1}{c}{ Biaya } & $\begin{array}{c}\text { Nilai } \\
\text { (Rp/rrg/LLG/thn) }\end{array}$ & \multicolumn{1}{c}{$\begin{array}{c}\text { Nilai } \\
\text { (Rp/org/ha/th) }\end{array}$} \\
\hline 1 & Biaya Tetap & 39.885 & $49.241,13$ \\
2 & Biaya Variabel & 386.111 & $476.680,25$ \\
\hline
\end{tabular}

Sumber (Source): Data Primer diolah Tahun 2018 (Primary data/processed 2018)

Menurut Soekartawi (2002), biaya tetap adalah biaya yang relatif tetap jumlahnya, dan terus dikeluakan walaupun produksi yang diperoleh banyak atau sedikit. Biaya tetap yang digunakan dalam mengelola kemiri terdiri dari biaya penggunaan alat, dimana perhitungan biaya alat-alat yang digunakan yaitu menggunakan perhitungan nilai penyusutan alat. Biaya penyusutan adalah pengurangan nilai alat tiap tahunnya. Sedangkan Alat yang digunakan terdiri dari beberapa alat dengan nilai penyusutan alat yang berbeda pula terdiri dari cangkul, 
ember, parang, dan bakul. Sedangkan biaya variabel Menurut Soekartawi (2002), merupakan biaya yang besar kecilnya dipengaruhi produksi yang diperoleh. Biaya variabel dalam mengelola kemiri terdiri dari biaya karung dan upah tenaga kerja. Karung tersebut digunakan untuk mengisi hasil panen, sedangkan upah tenaga kerja adalah hak yang diterima oleh buruh sesuai dengan hasil kerjanya.

\section{Pendapatan Petani}

Pendapatan petani adalah pendapatan yang diperoleh dalam kegiatan bertani, dimana pendapatan yang diperoleh berasal dari kemiri dan non kemiri. Pendapatan kemiri yang dimaksud dalam penelitian ini adalah penghasilan yang diterima responden dari kemiri selama satu musim panen selama satu tahun yang dinyatakan dalam rupiah.

Pendapatan non kemiri adalah pendapatan yang diperoleh responden selain berusaha sebagai petani kemiri yaitu pendapatan yang diperoleh diluar kemiri dalam kurun waktu satu tahun yang dinyatakan dalam rupiah. Berdasarkan hasil wawancara diketahui bahwa sumber pendapatan petani juga diperoleh dari kopi, kakao, pisang, vanili, dan randu, dimana hasil yang diperoleh tersebut sebagiannya dijual dan dikonsumsi secara pribadi terutama kopi.

Total pendapatan responden dalam penelitian ini adalah seluruh pendapatan yang diperoleh dalam kurun waktu satu tahun yang dinyatakan dalam rupiah.

Tabel 2. Total Pendapatan Petani.

Table 2. Total Income's Farmer.

\begin{tabular}{clll}
\hline No. & Sumber Pendapatan & \multicolumn{1}{c}{ Komponen } & Nilai \\
\hline 1. & Kemiri & Rata-rata & \\
& & Pendapatan (Rp/Org/LLG/Thn) & 2.630 .893 \\
& & Pendapatan (Rp/Org/Ha/Thn) & 3.417 .632 \\
\hline 2. & Non Kemiri & Rata-rata & \\
& & Pendapatan (Rp/Org/LLG/Thn) & 2.498 .925 \\
& & Pendapatan (Rp/Org/Ha/Thn) & 3.085 .092 \\
\hline
\end{tabular}

Sumber (Source): Data Primer diolah Tahun 2018 (Primary data/processed 2018)

Berdasarkan hasil penelitian menunjukkan bahwa pendapatan yang diperoleh dari kemiri lebih besar dibandingkan dengan pendapatan non kemiri, karena di kawasan hutan kemasyarakatan tidak dilakukan pengawasan secara intensif sementara terdapat banyak hama sehingga hasil yang diperoleh hanya tersisa dari yang tidak termakan hama yang masih layak jual sedangkan kemiri memiliki kulit keras yang tidak mudah diserang hama sehingga hasil produksi yang diperoleh banyak yang akan meningkatkan pendapatan yang diperoleh petani.

\section{Kontribusi Hasil Kemiri}

Kontribusi yang dimaksud dalam penelitian ini adalah sumbangan dari usaha kemiri yang diperoleh dari dalam kawasan hutan kemasyarakatan. Usaha kemiri di kawasan $\mathrm{HKm}$ Tangga Desa Selengen diusahakan oleh para petani untuk memperoleh pendapatan. Selain dari usaha kemiri, para petani juga memperoleh pendapatan dari usaha non kemiri.

Tabel 3. Kontribusi Kemiri.

Table 3. Contribution of Candlenut.

\begin{tabular}{clrccc}
\hline No & $\begin{array}{c}\text { Sumber } \\
\text { Pendapatan }\end{array}$ & $\begin{array}{c}\text { Jumlah } \\
\text { Pendapatan } \\
\text { (Rp/Org/LLG/Thn) }\end{array}$ & $\begin{array}{c}\text { Jumlah } \\
\text { Pendapatan } \\
\text { (Rp/Org/Ha/Thn) }\end{array}$ & $\begin{array}{c}\text { Kontribusi } \\
\text { /LLG (\%) }\end{array}$ & $\begin{array}{c}\text { Kontribusi/Ha } \\
\text { (\%) }\end{array}$ \\
\hline 1 & Kemiri & 2.630 .893 & 3.417 .632 & 51,3 & 52,6 \\
2 & Non Kemiri & 2.498 .925 & 3.085 .092 & 48,7 & 47,4 \\
\hline & Jumlah & $\mathbf{5 . 6 5 4 . 8 1 7}$ & $\mathbf{7 . 9 2 3 . 8 8 4}$ & $\mathbf{1 0 0}$ & $\mathbf{1 0 0}$ \\
\hline
\end{tabular}

Sumber (Source): Data Primer diolah Tahun 2018 (Primary data/processed 2018) 
Berdasarkan hasil penelitian menunjukkan bahwa kontribusi kemiri terhadap pendapatan petani lebih besar dibandingkan dari non kemiri. Usaha kemiri memberikan sumbangan cukup besar terhadap pendapatan petani dan pendapatan tersebut digunakan untuk memenuhi kebutuhan keluarga. Hasil produksi kemiri sebagian disalurkan ke rumah produksi kemiri untuk diolah menjadi produk olahan kemiri yaitu kemiri kupas dan minyak kemiri.

\section{Faktor Pendukung dan Penghambat Pengelolaan Kemiri}

Berdasarkan hasil wawancara yang diperoleh bahwa faktor pendukung dalam pengelolaan kemiri di HKm Tangga yaitu budidaya kemiri sangat mudah dikembangkan, tidak memerlukan pemeliharaan yang intensif, kegiatan panen yang sangat mudah dilakukan, teknologi alat yang digunakan bersifat tradisional yang mudah dijangkau oleh petani, dan proses pemasaran yang mudah dilakukan karena dijual secara langsung ke pengumpul.

Sedangkan faktor penghambat dalam pengelolaan kemiri yaitu kurangnya modal dan ketersediaan alat yang terbatas dalam pengolahan kemiri sehingga petani hanya mampu menjual kemiri dalam bentuk gelondongan saja yang akan mengurangi pendapatan yang diterimanya, serta kurangnya pengetahuan dan keterampilan yang dimiliki oleh petani.

\section{Strategi Peningkatan Pendapatan}

Berdasarkan hasil analisa penelitian terhadap keempat kategori yang termasuk kedalam faktor internal (kekuatan dan kelemahan) dan faktor eksternal (peluang dan ancaman), terdapat beberapa alternatif strategi yang dapat dilakukan untuk meningkatkan pendapatan petani HKm Tangga dari kemiri yang dapat dilihat pada Gambar berikut:

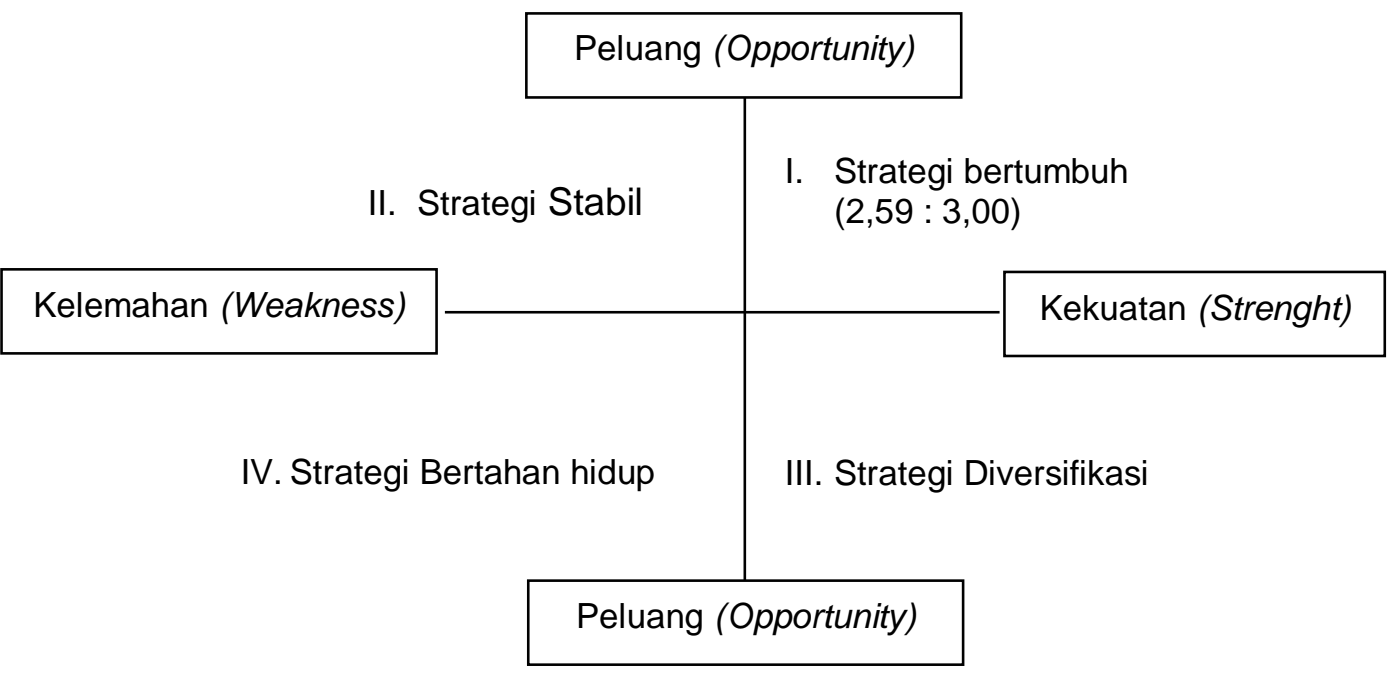

Gambar 4. Strategi Peningkatan Pendapatan Petani dari Pengelolaan Kemiri.

Figure 4. Farmers' Income Improvement Strategy from Management of Candlenut.

Gambar 4. diatas menunjukkan bahwa strategi peningkatan pendapatan petani dari usaha pengelolaan kemiri berada pada kuadran I atau strategi bertumbuh yakni mempunyai kekuatan dan peluang yang cukup besar (strategi SO), sehingga dapat mengandalkan kekuatan yang dimiliki dan memanfaatkan peluang yang ada artinya bahwa kekuatan yang dimiliki oleh petani Hutan Kemasyarakatan Tangga seperti mengembangkan potensi kemiri dengan keterampilan yang dimiliki oleh petani dengan memanfaatkan teknologi alat yang sederhana. Serta peningkatan budidaya dan pemeliharaan kemiri yang intensif dengan memanfaatkan lahan kawasan yang ada. 
Hal ini memberikan indikasi bahwa peluang peningkatan pendapatan petani Hutan kemasyarakatan Tangga meskipun menghadapi berbagai ancaman, namun kekuatan dari faktor internal masih dimiliki. Strategi yang harus diterapkan adalah menggunakan kekuatan untuk memanfaatkan peluang. Lebih jelasnya dapat dilihat pada Tabel berikut.

Tabel 4. Diagram Matriks Analisis SWOT Strategi Peningkatan Pendapatan Petani dari Usaha pengelolaan Kemiri.

Table 4. Matrix Diagram SWOT Analysis Farmer's Income Improvement Strategy Business of Candlenut Management.

\begin{tabular}{|c|c|c|}
\hline EFAS & $\begin{array}{l}\text { Strenght (S) } \\
\text { 1. Rata-rata petani HKm terampil } \\
\text { dan tidak memerlukan modal } \\
\text { dalam budidaya kemiri. } \\
\text { 2. Tidak dilakukan pemeliharaan } \\
\text { yang intensif, pemanenan } \\
\text { mudah dilakukan oleh semua } \\
\text { kalangan, dan pengangkutan } \\
\text { tidak memerlukan banyak } \\
\text { tenaga kerja. } \\
\text { 3. Keuntungan hasil panen cukup } \\
\text { tinggi } \\
\text { 4. Penyimpanan dalam jangka } \\
\text { waktu lama tidak } \\
\text { mempengaruhi kualitas kemiri. } \\
\text { 5. Mudah tumbuh dalam } \\
\text { berbagai kondisi, dan jumlah } \\
\text { produksi akan meningkat } \\
\text { apabila ukuran pohonnya } \\
\text { besar. }\end{array}$ & $\begin{array}{l}\text { Weaknessess (W) } \\
\text { 1. Jaringan rantai pemasaran } \\
\text { tidak diketahui oleh petani. } \\
\text { 2. Belum melakukan } \\
\text { pencatatan keuangan yang } \\
\text { baik. } \\
\text { 3. Keterbatasan pengetahuan, } \\
\text { alat, dan waktu untuk } \\
\text { melakukan pengolahan } \\
\text { 4. Memerlukan ruang tumbuh } \\
\text { yang tinggi, dan jumlah } \\
\text { produksi berkurang apabila } \\
\text { terdapat jenis tanaman lain } \\
\text { di sekelilingnya } \\
\text { 5. Jarak tanam mempengaruhi } \\
\text { jumlah produksi. }\end{array}$ \\
\hline $\begin{array}{l}\text { Opportunities (O) } \\
\text { 1. Pembudidayaan kemiri didukung } \\
\text { oleh pemerintah. Dan kemiri } \\
\text { menghasilkan buah yang } \\
\text { banyak. } \\
\text { 2. Tersedia rumah produksi yang } \\
\text { berperan sebagai pengumpul, } \\
\text { penyimpan dan pengering kemiri } \\
\text { gelondongan. } \\
\text { 3. Permintaan kemiri kontinyu } \\
\text { sepanjang tahun, dan } \\
\text { permintaan pasar semakin } \\
\text { meningkat setelah adanya rumah } \\
\text { produksi, dan akan bernilai } \\
\text { ekonomis yang tinggi apabila } \\
\text { diolah menjadi berbagai produk } \\
\text { olahan kemiri } \\
\text { 4. Teknologi alat-alat yang } \\
\text { digunakan sangat sederhana, } \\
\text { serta kenaikan harga BBM tidak } \\
\text { mengurangi biaya transportasi } \\
\text { pengangkutan kemiri. Tidak ada } \\
\text { biaya pajak dalam kegiatan } \\
\text { pengelolaan kemiri. } \\
\text { 5. Ketika musim hujan terjadi pada } \\
\text { saat menjelang musim panen } \\
\text { maka akan menguntungkan bagi } \\
\text { petani karena dapat membantu } \\
\text { proses pemanenan }\end{array}$ & $\begin{array}{l}\text { Strategi SO } \\
\text { Mengembangkan potensi kemiri } \\
\text { dengan meningkatkan kinerja } \\
\text { Sumber Daya Manusia (SDM) } \\
\text { dengan pemanfaatan teknologi } \\
\text { yang ada. Serta penguatan } \\
\text { kelembagaan dan mengadakan } \\
\text { pemeliharaan kemiri yang intensif } \\
\text { dengan memanfaatkan lahan } \\
\text { kawasan yang ada. }\end{array}$ & $\begin{array}{l}\text { Strategi WO } \\
\text { Adanya bantuan dari pemerintah } \\
\text { maka dapat diberikan pelatihan } \\
\text { khusus bagi petani untuk } \\
\text { pengolahan kemiri serta bantuan } \\
\text { alat pengolahannya untuk } \\
\text { meningkatkan nilai ekonomis } \\
\text { yang lebih bagi produk kemiri } \\
\text { sehingga dapat meningkatkan } \\
\text { pendapatan petani. }\end{array}$ \\
\hline $\begin{array}{l}\text { Threats (T) } \\
\text { 1. Kurangnya keterampilan dan } \\
\text { ilmu pengetahuan petani } \\
\text { dalam melakukan kegiatan } \\
\text { pengolahan. } \\
\text { 2. Kemiri membutuhkan ruang } \\
\text { sendiri untuk } \\
\text { pembudidayaannya. } \\
\text { 3. Penjualan dilakukan secara }\end{array}$ & $\begin{array}{l}\text { Strategi ST } \\
\text { Pembinaan kelompok tani dalam } \\
\text { melakukan pengelolaan kemiri, } \\
\text { pengembangan kelembagaan pasar, } \\
\text { serta kegiatan budidaya tanaman } \\
\text { kemiri dapat dilakukan dengan } \\
\text { mengatur jarak tanam dan pola } \\
\text { kombinasi tanaman agar tanaman }\end{array}$ & $\begin{array}{l}\text { Strategi WT } \\
\text { Penetapan harga kemiri yang } \\
\text { pasti agar tidak ada perselisihan } \\
\text { harga antara produsen (petani) } \\
\text { dengan pengepul. }\end{array}$ \\
\hline
\end{tabular}




\begin{tabular}{|l|l|l|}
\hline $\begin{array}{l}\text { ijon bertingkat, sehingga ada } \\
\text { perbedaan selisih harga. }\end{array}$ & kemiri dapat tumbuh dengan baik \\
untuk memperoleh jumlah produksi & \\
4inat masyarakat akan \\
berkurang jika permintaan \\
$\begin{array}{l}\text { pasar berkurang akan kemiri. } \\
\text { Harga kemiri murah pada saat } \\
\text { panen raya }\end{array}$ & yang banyak. & \\
\hline
\end{tabular}

Berdasarkan analisis SWOT pada Tabel 4. diatas, maka dalam strategi peningkatan pendapatan petani dari usaha pengelolaan kemiri terdapat beberapa alternatif strategi, diantaranya:

1. Strategi SO (Nilai 3,15 )

Strategi ini dibuat dengan menggunakan seluruh kekuatan dengan memanfaatkan peluang yang ada yaitu, mengembangkan potensi kemiri dengan meningkatkan kinerja Sumber Daya Manusia (SDM) dengan pemanfaatan teknologi yang ada. Serta penguatan kelembagaan dan mengadakan pemeliharaan kemiri yang intensif dengan memanfaatkan lahan kawasan yang ada. Menurut Syahrizal (2015, Djogo \&Hakim, 2003) mengatakan bahwa pembinaan secara terus menerus kelembagaan adalah suatu tatanan dan pola hubungan antara anggota masyarakat atau organisasi yang saling mengikar dan dapat menentukan bentuk antar manusia atau antar organisasi yang diwadahi dalam suatu organisasi untuk bekerja sama dan mencapai tujuan bersama. Pembinaan kelembagaan dilakukan guna meningkatkan kerjasama, agar mempunyai kelebihan pengetahuan, keterampilan, sikap dan perilaku serta mau berkorban untuk kemajuan kelompoknya (Raja ; Antara ; Anam, 2016). Hal terpenting lainnya adalah pemberdayaan ataupun partisipasi masyarakat hendaknya tanpa paksaan Syahrizal (2015, Mubyarto, 1994).

2. Strategi ST (Nilai 2,45 )

Strategi ini dibuat dengan menggunakan kekuatan yang dimiliki untuk mengatasi ancaman yang ada yaitu, Pembinaan kelompok tani dalam melakukan pengelolaan kemiri, pengembangan kelembagaan pasar, serta kegiatan budidaya tanaman kemiri dapat dilakukan dengan mengatur jarak tanam dan pola kombinasi tanaman agar tanaman kemiri dapat tumbuh dengan baik untuk memperoleh jumlah produksi yang banyak. Menurut Sanudin (2009) Pengembangan kelembagaan pasar bertujuan untuk menciptakan iklim kondusif untuk usaha petani. Pengembangan kelembagaan pasar dapat dilakukan dengan membentuk lembaga perkreditan, lembaga kerjasama usaha dengan pihak lain, dan sebagainya. Sedangkan pembinaan kelompok tani diarahkan pada kemampuan kelompok dalam melaksanakan peran dan fungsinya sebagai kelas belajar setiap anggota tani untuk berinteraksi guna meningkatkan pengetahuan, sikap dan keterampilan; wahana kerjasama; unit produksi, unit pengolahan dan pemasaran (Raja ; Antara ; Anam, 2016).

3. Strategi WO (Nilai 3,14)

Strategi ini dibuat dengan menghilangkan kelemahan yang ada untuk dapat memanfaatkan semua peluang yang ada, yaitu dengan adanya bantuan dari pemerintah maka dapat diberikan pelatihan khusus bagi petani untuk pengolahan kemiri serta bantuan alat pengolahannya untuk meningkatkan nilai ekonomis yang lebih bagi produk kemiri sehingga dapat meningkatkan pendapatan petani.

4. Strategi WT (Nilai 2,44)

Strategi W-T didapat dengan meminimalkan kelemahan untuk mengantisipasi ancaman yang ada, strategi yang dilakukan adalah penetapan harga kemiri yang pasti agar tidak ada perselisihan harga antara produsen (petani) dengan pengepul.

Hasil analisis terhadap berbagai alternatif strategi untuk mengoptimalkan pengembangan kemiri di HKm Tangga, diarahkan pada upaya peningkatan kapasitas dan keterampilan petani dalam aspek budidaya, pengolahan hasil sampai proses pemasarannya. Hal ini didasarkan pada ketersediaan potensi kemiri yang melimpah, namun kapasitas dan keterampilan yang dimiliki petani belum memadai. Untuk meningkatkan kapasitas dan 
keterampilan petani tersebut, bisa di lakukan dengan mefasilitasi penguatan kelembagaan kelompok tani (Anantanyu, 2011; Nasrul, 2012; Indrasari, Wulandari, and Bintoro, 2017). Secara subatansi kelembagaan berfungsi untuk memberikan pengaturan terkait interdependensi antar pemangku kepentingan dalam pelaksanaan pengelolaan sumberdaya (Ichsan, 2018). Serta penguatan tata kelola kelembagaan dapat dilakukan dengan melakukan kegiatan penyuluhan dan pelatihan. Tata kelola usaha seperti inovasi produk dan perbaikan jaringan pasar dilakukan dengan cara perbaikan kemasan produk (branding) untuk mengikat daya tarik konsumen. Dan tata kelola kawasan dapat dilakukan dengan menerapkan sistem agroforestri (pengaturan jarak tanam).

\section{Kesimpulan}

Kontribusi pendapatan yang diberikan dari usaha Kemiri (Aleurites moluccana) di dalam kawasan HKm Tangga adalah sebesar 51,3\% per luas lahan garapan per tahun atau $52,6 \%$ per hektar per tahun dengan total pendapatan Rp 2.630.893 /LLG/th atau Rp 3.417.632 /ha/th. Faktor pendukung dalam usaha Kemiri (Aleurites moluccana) di dalam kawasan $\mathrm{HKm}$ Tangga adalah tidak memerlukan modal dalam kegiatan penanaman, teknologi peralatan yang sederhana dalam kegiatan pemeliharaan, pemanenan yang mudah dilakukan dari semua kalangan, dan harga produksi yang cukup tinggi. Sedangkan faktor penghambat dalam usaha Kemiri (Aleurites moluccana) di dalam kawasan HKm Tangga kurangnya pengetahuan dan keterampilan yang dimiliki petani dilihat dari jenjang pendidikan formal yang ditempuh.

Berdasarkan keempat strategi peningkatan pendapatan dari usaha kemiri strategi SO (Strenght-Opportunity) memiliki nilai skor tertinggi 3,15 yaitu mengembangkan potensi kemiri dengan meningkatkan kinerja Sumber Daya Manusia (SDM) dengan pemanfaatan teknologi yang ada. Serta penguatan kelembagaan dan mengadakan pemeliharaan kemiri yang intensif dengan memanfaatkan lahan kawasan yang ada. Serta penguatan tata kelola kelembagaan dapat dilakukan dengan melakukan kegiatan penyuluhan dan pelatihan. Tata kelola usaha seperti inovasi produk dan perbaikan jaringan pasar dilakukan dengan cara perbaikan kemasan produk (branding) untuk mengikat daya tarik konsumen. Dan tata kelola kawasan dapat dilakukan dengan menerapkan sistem agroforestri (pengaturan jarak tanam).

\section{Daftar Pustaka}

Anantanyu, S. (2011). Kelembagaan petani: Peran dan Strategi Pengembangan Kapasitasnya. Jurnal Sosial Ekonomi Pertanian dan Agribisnis, 7(2), 102-109.

Husinsyah. 2006. "Kontribusi Pendapatan Petani Karet Terhadap Pendapatan Petani Di Kampung Mencimai." Epp 3 (1): 9-20.

Ichsan, A. C. (2018). Kinerja Pembangunan Kesatuan Pengelolaan Hutan Lindung Sungai Wain dan DAS Manggar di Provinsi Kalimantan Timur. Jurnal Belantara, 1(1).

Indrasari, Desi, Christine Wulandari, and Afif Bintoro. 2017. "Pengembangan Potensi Hasil Hutan Bukan Kayu Oleh Kelompok Sadar Hutan Lestari Wana Agung Di Register 22 Way Waya Kabupaten Lampung Tengah". 5 (1): 81-91.

Markum, Setiawan B, dan Sabani R. 2014. Hutan Kemasyarakatan Sebuah Ikhtiar Mewujudkan Hutan Lestari Masyarakat Sejahtera. Balai Pengelolaan Daerah Aliran Sungai Dodokan Moyosari Nusa Tenggara Barat: RA Visindo. ISBN 978-062-74279-07.

Menteri Lingkungan Hidup dan Kehutanan Republik Indonesia. 2016. "Peraturan Menteri Lingkungan Hidup Dan Kehutanan Republik Indonesia Nomor 83/MENLHK/SETJEN/KUM.1/2016 Tentang Perhutanan Sosial." Kementerian 
Lingkungan Hidup Dan Kehutanan, 1-45.

Menteri Kehutanan Republik Indonesia. 2007. "Peraturan Menteri Kehutanan Republik Indonesia Nomor P.21/Menhut-II/2009 Tentang Kriteria dan Indikator Penetapan Jenis Hasil Hutan Bukan Kayu Unggulan." Kementerian Kehutanan, 1-28.

Menteri Kehutanan Republik Indonesia. 2007. "Peraturan Menteri Kehutanan Republik Indonesia Nomor P.37/Menhut-II/2007 Tentang Hutan Kemasyarakatan." Kementerian Kehutanan, 1-22.

Menteri Kehutanan Republik Indonesia. 2006. "Peraturan Menteri Kehutanan Republik Indonesia Nomor P.55/Menhut-II/2006 Tentang Penataan Hasil Hutan Yang Berasal Dari Hutan Negara." Kementerian Kehutanan No. 1: 1-52.

Nasrul, W. (2012). Pengembangan Kelembagaan Pertanian Untuk Peningkatan Kapasitas Petani Terhadap Pembangunan Pertanian. Menara IImu, III(29), 166-174.

Raja, Eduardus, Antara made, dan Anam Haerul. 2016. "Strategi Pengembangan Usaha Pengelolaan Hutan Tanaman Rakyat Di Desa Bumi Beringin Kecamatan Luwuk Kabupaten Banggai” Jurnal e-katalogis 4 (1) : 215-228.

Sanudin. 2009. "Strategi Pengembangan Hutan Rakyat Pinus Di Kabupaten Humbang Hasundutan Sumatera Utara" Jurnal Analisis Kebijakan Kehutanan 6 (2) :131 - 149

Silamon, Rato Firdaus. 2014. Rencana Strategis Pengelolaan HHBK Kabupaten Lombok Utara Sebuah Produk Aksi Partisipatif. Program Studi Kehutanan. Universitas Mataram. Prosiding ISBN 978-602-71618-1-8.

Soekartawi. 2002. Analisis Usahatani. Universitas Indonesia Press, Jakarta.

Sugiyono. 2016. Metode Penelitian Kuantitatif Kualitatif dan R\&D. Alfabeta. Bandung.

Syahrizal. 2015. "Strategi Pengembangan Hutan Kemasyarakatan Dengan Pola Agroforestry Di Desa Amal Kecamatan Sindue Kabupaten Donggala". Jurnal Sains dan Teknologi Tadulako 4 (1) : 39-48

Waluyo dan A. I. Sari. 2014. Penguatan ekonomi kreatif masyarakat lereng Merapi melalui peningkatan keterampilan dan produktivitas usaha. Jurnal Pertanian. 2(11):307-317

WWF Indonesia Program Nusa Tenggara. 2012. Rencana Pengelolaan Hasil Hutan Bukan Kayu Di Kawasan HKm Kabupaten Lombok Utara. WWF Indonesia Program Nusa Tenggara.

WWF Indonesia Program Nusa Tenggara. 2016. Analisis Rantai Nilai dan Insentif Ekonomi Komoditas HHBK Unggulan Pulau Lombok. Yayasan WWF Indonesia 